\title{
REALISASI PRONOMINA DALAM BAHASA MOOI: ANALISIS TIPOLOGI MORFOLOGI
}

\author{
Realization of Pronoun in Mooi Language: \\ Morphology Tipology Analyzis \\ Winci Firdaus \\ Badan Pengembangan dan Pembinaan Bahasa \\ wincifirdaus@yahoo.com
}

\begin{abstract}
Abstrak
Penelitian ini membahas tentang realisasi pronomina. Tujuan dari penelitian ini mendeskripsikan bentuk realisasi pronomina bahasa Mooi. Metode yang digunakan dalam penelitian ini adalah metode deskriptif sinkronis, dengan teknik pengumpulan data adalah teknik cakap dan simak. Teknik analisis data adalah teknik analisis generalisasi yang meliputi beberapa tahapan dari penentuan bentuk dan satuan dalam korpus sampai pada pemeriksaan generalisasi morfologi. Hasil dari penelitian ini menunjukkan bahwa struktur kata ganti pada bahasa Mooi meliputi pronomina persona, pronomina milik, pronomina penanya, dan pronomina penunjuk. Bentuk pronomina dalam bahasa Mooi mengenal bentuk gender dan akan mengalami perubahan bunyi apabila berdampingan dengan kata ganti orang I, II, dan III.
\end{abstract}

Kata-kata kunci: pronomina, morfologi, bahasa Mooi

\begin{abstract}
This research discusses the pronouns realization. The purpose of this research is to describe the structure of pronouns realization in the Mooi language. The method used in this study is descriptive synchronic method, while data collection techniques are speaking and listening methods. Data analysis technique is generalization analysis techniques which include several stages of determining the shape and units in the corpus until the examination of morphological generalizations. The results of this research show that the structures of pronouns in the Mooi language include the personal, proprietary, interrogative and demonstrative pronouns. The forms of pronouns in Mooi recognize gender forms and will experience sound changes when appear side by side with pronouns I, II and III.
\end{abstract}

Keyword: pronouns, morphology, Mooi language

How to Cite: Firdaus, Winci. (2018). Realisasi Pronomina dalam Bahasa Mooi: Analisis Tipologi Morfologi, Ranah: Jurnal Kajian Bahasa, 7 (2), 180-193. doi: https://doi.org/10.26499/rnh.v7i2.496 


\section{PENDAHULUAN}

Bahasa adalah sarana utama dan vital untuk memenuhi kebutuhan berkomunikasi, baik mengutarakan ide, gagasan, pokok pikiran maupun maksud. Manusia sepanjang hidupnya akan terus-menerus berbahasa karena selama hidupnya manusia tidak mungkin putus dari komunikasi. Sarana komunikasi dibedakan menjadi dua, yaitu komunikasi verbal dan nonverbal.

Bahasa merupakan sistem tanda bunyi ujaran yang bersifat arbitrer atau sewenang-wenang. Bahasa mempunyai sistem yang sifatnya mengatur. Bahasa merupakan suatu lembaga yang memiliki pola-pola atau aturan-aturan yang dipatuhi dan digunakan (kadang-kadang tanpa sadar) oleh pembicara dalam komunitas saling memahami. Berdasarkan pengertian ini, secara substansi bahasa merupakan bunyi yang dihasilkan oleh alat ucap manusia. Hal ini sejalan dengan berbagai pendapat bahwa asal mula sebuah bahasa adalah bahasa lisan sehingga menurut hemat penulis bahwa bahasa lisan tersebut merupakan lambang bunyi yang dikeluarkan oleh alat ucap manusia. Bunyi bahasa diatur oleh tata bunyi dan karena itulah bahasa merupakan sistem. Kumpulan bunyi untuk menyebutkan sesuatu di luar. Biasa tidak diatur secara ketat, tetapi semaunya penutur sesuai dengan konvensi masyarakat.

Chaer (2015) mengungkapkan juga pendapatnya bahwa sebagai alat komunikasi manusia, bahasa adalah suatu sistem yang bersifat sistematis dan sekaligus sistemis, yang dimaksud dengan istilah sistematis adalah bahasa itu tersusun menurut suatu pola, tidak tersusun secara acak, dan tidak sembarangan. Sementara itu, istilah sistemis adalah bahasa tersebut bukan sistem tunggal, melainkan terdiri atas beberapa subsistem, di antaranya subsistem fonologi, morfologi, sintaksis, dan semantik.

Penggunaan bahasa dalam interaksi sosial berubah-ubah menurut who speak, what language, to whom, when, dan to what end. Dengan kata lain, ketika seseorang ingin berujar ada bermacam-macam variasi bentuk yang akan dipilih untuk diucapkan (Prayogi, 2013).

Bahasa daerah merupakan sebuah identitas dan kekayaan suatu kelompok masyarakat yang dijadikan sebagai alat tutur dalam berkomunikasi dengan sekelompok masyarakat bahasa. Ada ungkapan “Bahasa menunjukkan bangsa”. Ungkapan ini berarti tutur kata seseorang akan menunjukkan bagaimana sifat dan watak orang itu. Alangkah indahnya keberagaman seni, ragam dialek, dan tradisi di setiap daerah di Indonesia. Dalam era Globalisasi keberadaan bahasa daerah menghadapi situasi yang 
mengkhawatirkan. Bahasa daerah mulai ditinggalkan penuturnya dalam pergaulan atau kegiatan antarmanusia karena dominannya bahasa asing yang menguasai berbagai bidang. Keadaan itu banyak dirasakan oleh pengguna bahasa daerah yang, antara lain, menyadari bahwa bahasa daerahnya kehilangan otoritas publiknya dan menjadi teks yang terkesan eksklusif.

Dalam linguistik mikro kita mengenal ilmu yang mempelajari asal mula pembentukan kata atau sistem pembentukan kata yang disebut morfologi. Morfologi inilah yang kemudian akan mengkaji tentang sistem pembentukan kata dan bagianbagiannya. Dalam penelitian penulis mencoba membahas tentang relasi pronomina dan afiksasi dalam bahasa Mooi. Morfologi dapat dipahami sebagai cabang ilmu linguistik yang mempelajari struktur internal pembentukan kata (Ariyani, 2014).

Pronomina merupakan kata yang dipakai untuk mengacu ke nomina lain. Bila dilihat dari fungsinya, pronomina biasanya menduduki yang biasanya diisi oleh nomina, seperti subjek, objek, dan pada kalimat tertentu dapat menduduki fungsi predikat. Dalam bahasa Indonesia pronomina dibedakan menjadi tiga, yaitu pronomina penunjuk persona, pronomina penunjuk, dan pronomina penanya (Laili, 2012).

Adapun yang menjadi alasan penulis melakukan penelitian tentang realisasi pronomina dan afiksasi dalam bahasa Mooi karena bahasa tersebut sudah jarang dipakai oleh penuturnya dan tidak banyak referensi tertulis sehingga bahasa tersebut bisa jadi lambat-laun akan terancam punah, walaupun ada beberapa hasil penelitian tentang bahasa Mooi yang pernah dilakukan oleh beberapa pakar bahasa.

Bahasa Mooi dituturkan oleh penduduk Kampung Maribu, Distrik Sentani Barat, Kabupaten Jayapura, Provinsi Papua. Berdasarkan penghitungan dialektometri, isolek Mooi merupakan sebuah bahasa dengan persentase perbedaan berkisar 94,50-100\% jika dibandingkan dengan bahasa sekitarnya, yaitu bahasa Sentani dan Ormu (Tim Pemetaan Bahasa, 2013).

SIL (2006) mengidentifikasikan bahasa Mooi yang terdapat di Papua dengan nama bahasa Mooi, Mosana, dan Mekwei. Jumlah penutur bahasa Mooi yaitu 1.200 orang (1987), dengan kategori Moribound atau bahasa hampir punah. Menurut SIL bahasa ini memiliki nama lain yaitu demenggong, Waibron, Bano, Menggei, Menggwei, Mooi, Munggai, Mungge, dan Munkey. 
Lokasi tutur bahasa Mooi meliputi kawasan yang berada di Distrik Genyem Sentani Barat, yaitu wilayah Kampung Maribu, Kampung Waibrong, Kampung Kendate dan Kampung Sabron Donay.

Nenek moyong suku Mooi berasal dari Genyem. Kata Mooi artinya "pemandangan matahari sore yang kemerah-merahan dan agak berkabut di atas bukit". Pada tahun 1912 Injil masuk ke teluk Demaenggong dibawa oleh Yakob Suae yang berasal dari desa Entyebo, orang Mooi yang pertama kali menerima injil adalah Klen Wandadaya.

Karena kurangnya umat, semua orang yang berada di dataran Wambutson harus turun ke pantai dan membentuk satu kampung untuk menerima Injil. Pada tahun 1940an terjadi perang dunia II antara Amerika dan Jepang. Karena takut akan bahaya, semua masyarakat yang berada di sekitar pantai pindah ke daratan dan membentuk perkampungan-perkampungan baru. Tiap klan memiliki seorang kepala suku dan tiap kampung dipimpin oleh Karano sebagai seorang pemimpin dan untuk memudahkan pengawasan dari pemerintah Hindia Belanda, maka seluruh masyarakat diperintah untuk membentuk satu perkampungan Demanggong yang sekarang disebut desa Maribu.

Pengertian kata Mooi menurut masyarakat berarti satu bahasa yang artinya mereka semua berasal dari rumpun yang memiliki bahasa yang sama, bahasa daerah yang mereka pakai sehari-hari dalam kehidupan mereka. Dalam kehidupan sehari-hari di kalangan para pemuda dan pelajar, pemakaian bahasa Mooi sebagai bahasa pengantar sudah jarang dipergunakan, kecuali kalangan orang tua sebagai alat komunikasi setiap hari.

Berdasarkan masalah yang telah diuraikan di atas, penulis menentukan masalah penelitian ialah bagaimana realisasi pronomina dalam bahasa Mooi?

\section{LANDASAN TEORI}

Menurut Basalama dalam Madji (2014) bahwa kata ganti atau pronomina adalah salah satu kata yang menggantikan kata benda atau kata ganti lainnya, yang digunakan untuk menghindari kejanggalan atau pengulangan-pengulangan yang bersifat monoton. Hal ini senada dengan pendapat (Kridalaksana, 2006). Pronomina adalah kategori yang berfungsi untuk menggantikan nomina. Apa yang digantikannya itu disebut anteseden. Anteseden itu ada di dalam atau di luar wacana (di luar bahasa). Sebagian pronomina kategori ini tidak bisa berafiks, tetapi beberapa di antaranya bisa direplikasikan, yakni 
kami-kami, dia-dia, mereka-mereka, dan beliau-beliau, dengan pengertian 'meremehkan' atau 'merendahkan'. Kata pronomina dapat dijadikan frase pronomina, seperti aku ini, kamu sekalian, dan mereka semua. Berdasarkan beberapa pendapat di atas dapat dikatakan bahwa yang dimaksud dengan pronomina adalah kata-kata yang digunakan untuk menggantikan diri dari manusia, dan segala kata yang dipakai untuk menggantikan kata benda atau kata yang dibendakan.

Afiksasi adalah proses pembubuhan afiks pada bentuk dasar (Muslich, 2008). Pembubuhan afiks yang dimaksud adalah penambahan prefiks, infiks, dan sufiks pada kata atau bentuk dasar. Kata atau bentuk dasar itu berupa kata atau bentuk bebas dan kata atau bentuk terikat. Bentuk bebas adalah kata yang dapat berdiri sendiri sebagai satu kata, sementara bentuk terikat adalah kata yang tidak berdiri sendiri atau bentuk tersebut bergantung pada kata yang lain.

\section{METODE PENELITIAN}

Metode penelitian merupakan alat, prosedur, dan teknik yang dipilih dalam melaksanakan penelitian (dalam mengumpulkan data). Metode penelitian bahasa berhubungan erat dengan tujuan penelitian bahasa. Penelitian bahasa bertujuan mengumpulkan dan mengkaji data, serta mempelajari fenomena-fenomena kebahasaan (Djajasudarma, 2010).

Metode utama yang digunakan adalah metode deskriptif sinkronis, yang berusaha memberikan gambaran objektif mengenai sistem morfologi suatu bahasa dengan ujaran yang dipakai secara otentik oleh penutur bahasa itu pada masa kini. Data yang dianalisis dikumpulkan dalam bentuk ujaran-ujaran yang benar-benar dipakai oleh masyarakat pemakai bahasa Mooi pada waktu sekarang.

Teknik yang digunakan dalam pengumpulan data adalah menggunakan metode cakap (Sudaryanto, 1993) dan metode simak (Mahsun, 2007). Metode cakap dilakukan dengan teknik cakap semuka, dan metode simak dilakukan dengan teknik sadap dan diikuti dengan teknik lanjutan berupa teknik catat dan teknik sadap. Metode pustaka juga digunakan dalam penelitian ini. Hal ini bertujuan untuk memperoleh informasiinformasi terkait objek penelitian. Teknik pemancingan korpus akan dilakukan dengan langkah berikut.

(1) Pemancingan korpus dengan terjemahan.

(2) Pemancingan korpus dengan terjemahan terbalik. 
(3) Pemancingan korpus dengan tanya jawab.

(4) Pemancingan korpus secara analisis berdasarkan korpus yang telah terkumpul untuk mendapatkan korpus lebih lanjut.

Proses analisis data dalam penelitian menempuh prosedur sebagai berikut.

(1) Menentukan makna bentuk-bentuk dan satuan dalam korpus. Tujuannya ialah untuk membuat korpus lebih mudah dibaca dan dimengerti oleh peneliti untuk keperluan analisis.

(2) Mentranskripsikan data.

(3) Melakukan segmentasi, dalam hal ini dicoba memisah-misahkan bagian dari katakata dan ujaran-ujaran dalam korpus sesuai dengan bagian-bagian yang berulang, kemungkinan bergabung, dan arti atau fungsi butir yang sudah dapat dilacak.

(4) Melakukan klasifikasi dan perbandingan antara berbagai bentuk dalam korpus, semua bentuk dan satuan yang muncul dalam korpus dikumpulkan dan dibandingkan (morfem, kata, frasa, klausa, dan kalimat), lalu dikelompokkan ke dalam kelompok struktural sejenis.

(5) Membuat generalisasi, dari kumpulan butir dalam korpus yang telah dikelompokkan secara struktural dan fungsional itu, dibuat generalisasi morfologi bahasa Mooi.

(6) Melakukan pemeriksaan generalisasi, setiap generalisasi morfologi yang dibuat dalam penelitian ini diperiksa dan diuji dengan korpus yang ada dan kalau perlu dengan informan supaya tidak sampai terjadi generalisasi yang salah, tidak tepat, atau menyesatkan.

Populasi penelitian ini ialah bahasa yang dipakai masyarakat penutur asli bahasa Mooi di Kampung Maribu, Kabupaten Papua, Provinsi Papua. Sampel penelitian ialah penutur asli bahasa Mooi, penutur asli yang dijadikan informan dalam penelitian ini diambil dari penduduk asli Kampung Maribu. Syarat-syarat yang harus dipenuhi untuk menjadi informan dalam penelitian ini adalah:

a) penutur asli bahasa Mooi;

b) pria atau wanita yang sudah dewasa (16-60 tahun);

c) sekurang-kurangnya berpendidikan SD;

d) tidak pernah terlalu lama meninggalkan daerah asal;

e) mempunyai kesehatan yang baik;

f) tidak mempunyai cacat bicara seperti gagap, pelo, dan bindom; 
g) bersedia menjadi informan dan mempunyai cukup waktu untuk penelitian ini.

\section{PEMBAHASAN}

\section{Deskripsi Pronomina}

Pronomina atau kata ganti adalah bagian yang penting dan mestinya kita pahami dengan baik. Pronomina merupakan kata yang digunakan untuk menggantikan orang atau benda.

\subsection{Pronomina Persona}

\subsubsection{Pronomina Tunggal}

a. Kata Ganti Orang Pertama Tunggal

$\begin{array}{lll}\text { ka } & \text { 'saya` } & \\ \text { kat } & \text { `aku` } & \\ \text { kat asyu } & \text { ap tong (laki-laki) } \\ \text { kat asyu } & \text { ap trung (perempuan) } \\ \text { 'saya pergi` } & \end{array}$

b. Kata Ganti Orang Kedua Tunggal

kmot 'engkau, kau, anda, kamu`

komot asyu nap tong

komot asyu nap trung

`engkau pergi`

c. Kata Ganti Orang Ketiga Tunggal

nomot 'dia`

$\begin{array}{lll}\text { nomot } & \text { asyu } & \text { aptong (laki-laki) } \\ \text { nomot } & \text { asyu } & \text { ap trung (perempuan) }\end{array}$

'dia pergi`

Kata ganti orang ketiga tunggal harus dibedakan antara laki-laki dan perempuan.

Contoh:

nomot do 'dia laki-laki`

nomot tengga 'dia perempuan`

Dalam penerapannya bentuk do dan tengga berubah-ubah seperti tong dan trung.

bisang atong 'dia (laki-laki) bertanya`

bisang atrung 'dia (perempuan) bertanya`

1.1.2 Pronomina Jamak

a. Kata Ganti Orang Pertama Jamak

\begin{tabular}{|c|c|c|}
\hline kame, & & kami` \\
\hline kame & wasi & se \\
\hline kami & tidur & sedang \\
\hline
\end{tabular}

'Kami sedang tidur.' 
b. Kata Ganti Orang Kedua Jamak

komo kamu, kalian`

komo asyu ap trung (perempuan)

komo asyu ap tong (laki-laki)

'kamu pergi'

c. Kata Ganti Orang Ketiga Jamak

$\begin{array}{lll}\text { nomo } & \text { `mereka` } & \\ \text { nomo } & \text { keten } & \text { se } \\ \text { mereka } & \text { lapar sedang }\end{array}$

'Mereka sedang lapar.'

Kata ganti dalam bahasa Mooi akan mengalami perubahan bunyi. Perubahan bunyi tersebut tidak bisa berdiri sendiri, harus digandeng dengan kata bantu orang I, II dan III. Susunan tersebut sebagai berikut.

kale asyu apdu

kmole asyu apde

nomole asyu apdang

nomole asyu apdung

kamale asyu yapdang

komole asyu kapdei

nomole asyu napdang

Contoh lain:

ka wasi but apdu

komole wasi but apde nomole wasi but apdeng

nomole wasi but apdung

kamele wasi but yapdang

komole wasi but kapdei

nomole wasi but napdeng

$$
\begin{aligned}
& \text { `saya pergi } \\
& \text { `engkau pergi } \\
& \text { `dia (L) pergi } \\
& \text { `dia (P) pergi` } \\
& \text { 'kami pergi } \\
& \text { 'kamu pergi } \\
& \text { ‘mereka pergi }
\end{aligned}
$$

`saya tidur`

‘engkau tidur`

‘dia (L) tidur`

'dia (P) tidur'

'kami tidur'

‘kamu tidur’

‘mereka tidur`

1.2 Pronomina Milik/Empunya

a. Bentuk Kata Ganti Menyatakan Milik

$\begin{array}{ll}\text { kandei } & \text { 'ku’ } \\ \text { kmong } & \text { 'mu` } \\ \text { nomong } & \text { 'nya' } \\ \text { kameng } & \text { 'kita` } \\ \text { komong } & \text { 'kalian` } \\ \text { nomong } & \text { 'mereka’ }\end{array}$

b. Contoh Penerapan dalam Bentuk Kalimat

Penempatan kata milik seperti 'ku’, ‘mu’, `nya', 'kita`, 'kalian`, dan `mereka` pada bahasa Mooi strukturnya terbalik, berbeda dengan bahasa Indonesia. 
contoh:

\begin{tabular}{|c|c|}
\hline kandei & samsepa \\
\hline ku & buku \\
\hline \multicolumn{2}{|l|}{ 'bukuku` } \\
\hline nomong & $m b o$ \\
\hline nya & babi \\
\hline \multicolumn{2}{|l|}{ ‘babinya` } \\
\hline komong & denak tetat \\
\hline kalian & anak-anak \\
\hline
\end{tabular}

\begin{tabular}{|c|c|}
\hline kmong & ando \\
\hline ku & anjing \\
\hline \multicolumn{2}{|c|}{ `anjingmu` } \\
\hline kameng & yap \\
\hline kita & rumah \\
\hline \multicolumn{2}{|c|}{ 'rumah kita` } \\
\hline nomong & pala \\
\hline mereka & panah \\
\hline 'panah m & \\
\hline
\end{tabular}

\subsection{Pronomina Penanya}

a. nande `siapa`

Kata ini biasanya digunakan untuk menyatakan orang. Berikut contoh dalam bentuk kalimat.

Nje nande?

Nggo nande?

'Ini siapa`?

Komong sandu

'Itu siapa'?

Nande syoli se?

'Siapa namamu’?

'Perlu siapa`?

Nande syoli se kasing matre?

'Siapa yang dicari’?

b. kandi 'mana`

Kata ini digunakan untuk menyatakan pilihan dari beberapa orang, hal, atau barang.

Contoh:

1) orang

Kandi syoli kasing matre? 'Orang mana yang dicari`?

Nandese kasing matre? 'Siapa yang dicari?

2) barang

Sengga alutse kasing emtre? ‘Barang apa yang dicari`?

3) hal

Kandi alai kaktre? 'Hal mana yang kau piker’?

Sengga simya alai kaktre? ‘Hal apa yang kau piker`?

c. kmo `mengapa`

Kata ini digunakan untuk menanyakan sebab, alasan, atau perbuatan.

Contoh:

Kmo masi senggatale?

Kmo sengga use kongatre?

Kmo senggale
`Mengapa kakimu`?

`Mengapa kau menangis`?

‘Mengapa kau’?

d. nje/nggo 'berapa'

nNe dasi kandiyam? 'berapa ikan ini`? 
Nggo mbo nak kandiyam? ‘Berapa anak babi itu`?

e. kmong 'bagaimana`

Kata kmong digunakan untuk menanyakan keadaan.

Comtoh:

Kmong sanduk ka senggatase? ‘Bagaimana keadaanmu’?

Kmong yapma nenggetreka senggatase? `Bagaimana kehidupan keluargamu`?

f. sengga `apa`

Kata “apa” sengga, untuk menanyakan benda.

Contoh:

\begin{tabular}{|c|c|c|}
\hline$a ?$ & 'Benda apa`? & Sengga do? \\
\hline Vje sengga? & 'Ini apa`? & Nggo sengga? \\
\hline
\end{tabular}

\subsection{Pronomina Penunjuk}

Kata ganti penunjuk adalah kata ganti untuk menunjukkan sesuatu. Dalam bahasa Mooi kata ganti penunjuknya adalah sebagai berikut.

\begin{tabular}{|c|c|}
\hline nje & ‘ini` \\
\hline nggo & `itu` \\
\hline njene & $` \operatorname{sini}{ }^{\prime}$ \\
\hline nje se & `di sini` \\
\hline nggo se & ‘di sana`` \\
\hline nje trambu se & `ada di sini` \\
\hline nggo trambu se & `ada di sana` \\
\hline nje ndi dase & `ada di sebalah sini` \\
\hline nggo ndi dase & `ada di sebelah sana \\
\hline njene se & `ke sini` \\
\hline nggone se & `ke sana` \\
\hline nje sri & ‘dari sini` \\
\hline nggo sri & `dari sana` \\
\hline kandisri & ‘dari mana` \\
\hline kandine & `ke mana` \\
\hline
\end{tabular}

Contoh penerapan dalam kalimat

Nje syoli simya damtong.

`Orang ini sedang makan`.

Nggo kambung alut bu syop trung.

Njne kundei, kata ma!

Nggone nalai.Nggo syoli peku.

Kandai simya kanterambuse?

Komong alut nggodi dase?

Se, nggotrambuse?

$\mathrm{Ne}$, nggondi dase!

'Perempuan itu sedang mencuci barang`.

`Mari sini, cepatlah`!

'Pergi sana. Orang itu tidak baik.'

‘Barang saya ada di mana`?

‘Barang mu ada di sebelah kah'?

‘Mungkin, ada di situ kah`?

'Ya, ada di sebelah sana`! 


\section{Struktur Pronomina bahasa Mooi}

2.1 Struktur Pronomina Persona dan Pronomina Milik/Empunya

Kalimat 1

$\begin{array}{lllll}\text { kale } & \text { alut } & \text { nandale } & \text { ati } & \text { ong } \\ \text { saya }(\mathrm{ku}) & \text { barang } & \text { siapa yang } & \text { ambil } & \text { meng }\end{array}$

‘Siapa yang mengambil barangku (saya)’?

Kalimat 2

$\begin{array}{lll}\text { Komole } & \text { ati } & \text { te } \\ \text { engkau } & \text { yang ambil } & \text { meng }\end{array}$

`Engkau yang ambil`.

Kalimat 3

Nandale Sentani Ne asyu nap tong

Siapa yang Sentani ke pergi akan ber

‘Siapa yang akan pergi ke Sentani’?

Kalimat 4

nomole asyu nap deng

mereka yang pergi akan

'Mereka yang akan pergi.'

\section{Pembahasan Struktur Pronomina Persona}

1. Seandainya penutur ingin segera pergi/berangkat, pada kata tersebut ditambah dengan akhiran se.

Contoh:

kat asyu se 'saya mau berangkat`.

kmot asyu se ‘kamu mau berangka`.

Di sini akhiran se menunjukkan akan atau segera.

2. Bila itu saya yang pergi, penutur dapat mengatakan Kale asyu ap du.

Pada bagian ini kata ganti orang pertama, kedua, dan ketiga tunggal dan jamak mendapat akhiran "le".

Contoh:

$\begin{array}{llll}\text { kat } & + & l e & =\text { kale } \\ \text { kmot } & + & l e & =\text { kmole } \\ \text { nomot } & + & l e & =\text { nomole } \\ \text { kamet } & + & l e & =\text { kamele }\end{array}$

3. Pada bentuk tunggal. Orang I, II, dan III dipakai ap, dan pada jamak orang I, II, dan III dipakai:

$\begin{array}{ll}\text { yap } & \text { 'kami` } \\ \text { kap } & \text { 'kamu` } \\ \text { nap } & \text { 'mereka` }\end{array}$


4. Dengan perubahan bunyi pada $d u$, de, dan dang, bunyi “ap" tidak bisa berdiri sendiri, harus digandeng dengan kata bantu orang I, II, dan III. Dengan susunan sebagai berikut.
kale asyu apdu
kmole ayu apdu
`saya pergi`
‘engkau pergi`
nomole asyu apdang
nomole asyu apdung
'dia (l) pergi`
'dia (p) pergi`
kami pergi
kamale asyu yapdang
'kamu pergi`
komole asyu kapdei
'mereka pergi`
ka wasi but apdu
`saya akan tidur`
komole wasi but apdu 'engkau tidur'
'dia (l) tidur`
nomole wasi but apdeng
'dia (p) tidur`
kamale wasi but yapd.
'kami tidur'
komole wasi but kap dei
'kamu tidur`
nomole wasi but napdang
‘mereka tidur`

\subsection{Struktur Pronomina Penanya}

Kalimat 1

Sengga simya?

apa barang (benda)

‘Benda (barang) apa`?

Kalimat 2

Nje nande?
ini siapa?

'Siapa ini`?

Kalimat 3

$\begin{array}{lllll}\text { Sengga } & \text { simya } & \text { alai } & \text { kak } & \text { tre? } \\ \text { apa } & \text { barang } & \text { pikir } & \text { hal } & \text { di }\end{array}$

‘Hal apa yang dipikir’?

Kalimat 4

$\begin{array}{llll}\text { Kmong } & \text { masi } & \text { sengga } & \text { le? } \\ \text { mu } & \text { kaki } & \text { apa } & \text { meng }\end{array}$

‘Mengapa kakimu`?

Kalimat 5

$\begin{array}{llll}\text { Kmo sengga } & \text { use } & \text { kongatre? } \\ \text { kau mengapa } & \text { tangis } & \text { meng }\end{array}$

‘Mengapa kau menangis`?

Kalimat 6

Nje dasi kandiyam?
ini Ikan berapa
'Berapa ikan ini`?


Kalimat 7

$\begin{array}{llll}\text { Nggo donak } & \text { nenggalai-nenggalai } & \text { kandiyam? } \\ \text { itu } & \text { anak-anak } & \text { semua (banyak) } & \text { berapa } \\ \text { 'Berapa banyak anak-anak itu?' } & \end{array}$

Kalimat 8

Kmong yap ma nenggetre $k a$ sangga tase?
$\mathrm{mu}$ rumah dalam hidup/tinggal lah bagaimana `Bagaimana hidup keluargamu`?

Kalimat 9

Nggo kembali blap yem ka sengga tase? itu kerja biar kan di bagaimana

‘Bagaimana kelanjutan pekerjaan itu’?

\section{Pembahasan Struktur Pronomina Penanya}

1. Kata "se" menunjukkan pada diri sendiri dalam bentuk tunggal atau jamak. Penulisannya setelah menyebut nama diri (lihat contoh di atas).

2. Awalan me dan di dibentuk oleh kata bantu:

$\begin{array}{llll}\text { kasing } & \text { matre }(l) & \text { kasing } & \text { matru }(p) \\ \text { cari } & \text { me/di } & \text { cari } & \text { me/di } \\ \text { ‘mencari / } & \text { dicari } & \text { ‘mencari / dicari }\end{array}$

2.3 Struktur Pronomina Penunjuk

Kalimat 1

Nje syoli simya dam tong.

ini orang makanan makan sedang

`Orang ini sedang makan`.

Kalimat 2

Nggo kambung alut busyop trung.

itu perempuan barang cuci sedang

'Perempuan itu sedang mencuci barang’.

Kalimat 3

$\begin{array}{lll}\text { Kande simya kantarambuse? } \\ \mathrm{ku} & \text { barang ada di mana? }\end{array}$

`Barang saya ada di mana`?

Kalimat 4

$\begin{array}{llll}\text { Nje ne kundei } & \text { kata } & \text { ma. } \\ \text { ini ke mari } & \text { cepat } & \text { lah }\end{array}$




\section{PENUTUP}

Berdasarkan analisis data primer dan sekunder, dapat disimpulkan bahwa bahasa Mooi memiliki pronomina. Relasi pronomina dalam bahasa Mooi meliputi: pronomina persona, pronomina milik, pronomina penanya, dan pronomina penunjuk.

Hal yang unik dalam pronomina bahasa Mooi adalah 1) mengenal bentuk gender yang dibedakan dengan tegas; 2) pronomina akan mengalami perubahan bunyi apabila berdampingan dengan kata ganti orang ke I, II dan III; 3) pada pronomina persona, kata ganti jamak dalam bahasa Mooi akan mengalami perubahan bunyi. Perubahan bunyi tersebut tidak bisa berdiri sendiri, harus digandeng dengan kata bantu orang I, II dan III. Akhiran -se menunjukkan pada diri sendiri dalam bentuk tunggal atau jamak, penulisannya setelah menyebut nama diri.

\section{DAFTAR PUSTAKA}

Ariyani, F. (2014). Distribusi Verba Berfrefiks (N-) Pada Bahasa Lampung dalam Kitab Kuntara Raja Niti dan Buku Ajar. Ranah: Jurnal Kajian Bahasa, 3 (2), 124-134. https://doi.org/10.26499/rnh.v3i2.43

Chaer, A. (2015). Tata Bahasa Dasar Bahasa Indonesia. Bandung: PT Remaja Rosdakarya.

Djajasudarma, F. (2010). Metode Linguistik Ancangan Metode Penelitian dan Kajian. Bandung: Refika Aditama.

Kridalaksana, H. (2006). Kelas Kata dalam Bahasa Indonesia. Edisi Kedua. Jakarta: PT Gramedia Pustaka Utama.

Laili, I. (2012). Pronomina Penunjuk dalam Bahasa Minangkabau. Komposisi: Jurnal Pendidikan Bahasa, Sastra, dan. Komposisi: Jurnal Pendidikan Bahasa, Sastra, Dan Seni, 13 (1). https://doi.org/10.24036/komposisi.v13i1.3930

M.S, Mahsun. (2007). Metode Penelitian Bahasa. Jakarta: Raja Grafindo Persada.

Madji, S.A. (2014). Pronomina dalam Bahasa Banggai. (Doctoral Dissertation). Universitas Negeri Gorontalo, Gorontalo.

Muslich, M. (2008). Tata Bentuk Bahasa Indonesia. Jakarta: PT Bumi Aksara.

Prayogi, I. (2013). Pergeseran Pemakaian Pronomina Persona dalam Bahasa Indonesia Gaul. Ranah: Jurnal Kajian Bahasa, 2 (2), 38-55. https://doi.org/10.26499/rnh.v2i2.234

S.I.L. (2006). Language of Indonesia. Jakarta: SIL Cabang Indonesia.

Sudaryanto. (1993). Metode dan Aneka Tehnik Analisis Bahasa: Pengantar Penelitian Wahana Kebudayaan secara Linguistik. Yogyakarta: Duta Wacana University Press.

Tim Pemetaan Bahasa. (2013). Bahasa dan Peta Bahasa di Indonesia. Jakarta: Badan Pengembangan dan Pembinaan Bahasa. 